\title{
Cloning, Expression and Location of the Streptococcus lactis Gene for Phospho- $\beta$-D-galactosidase
}

\author{
By SUMIO MAEDA† AND MICHAEL J. GASSON* \\ Food Research Institute, Shinfield, Reading RG2 9AT, UK
}

(Received 3 April 1985 ; revised 25 September 1985)

\begin{abstract}
Genes for lactose catabolism and proteinase production in Streptococcus lactis 712 are encoded by a $56.5 \mathrm{~kb}$ metabolic plasmid, pLP712. A lactose mini-plasmid of only $23.7 \mathrm{~kb}$, pMG820, was constructed by introducing two deletions into pLP712, and was cloned as two segments of DNA into the Escherichia coli vector pAT153 using restriction endonuclease Pst I. The lactose genetic region of pLP712, which has been defined by deletion and restriction mapping, was cut into two parts by this process. When the smaller $10 \cdot 8 \mathrm{~kb}$ segment of pMG820 DNA was present, the key lactic streptococcal lactose splitting enzyme, phospho- $\beta$-D-galactosidase, was expressed in $E$. coli. The gene for phospho- $\beta$-D-galactosidase was more precisly located by introducing a series of deletions into cloned DNA by in vitro manipulations and then assaying for enzyme activity. The presence of this phospho- $\beta$-D-galactosidase activity was correlated with the production of a $58 \mathrm{kDa}{ }^{35} \mathrm{~S}$-labelled protein both by $E$. coli minicells and after coupled transcription and translation of cloned DNA. The product of a second gene, a $37 \mathrm{kDa}$ protein ('protein X'), and a possible truncated phospho- $\beta$-D-galactosidase protein of $16 \mathrm{kDa}$ were also detected in minicells.
\end{abstract}

\section{INTRODUCTION}

In many bacteria lactose catabolism is initiated by permease-promoted uptake of lactose and the generation of glucose and galactose by $\beta$-galactosidase. The biochemistry of these reactions has been studied intensively and the genes for lactose metabolism are amongst the best characterized. In contrast, a small number of Gram-positive bacteria possess a quite distinct and less well characterized pathway that begins with the phosphorylation of lactose upon uptake by the phosphoenolpyruvate-dependent phosphotransferase system (PTS). The lactose phosphate produced is converted into glucose and galactose 6 -phosphate by phospho- $\beta$-galactosidase. This enzyme from Lactobacillus casei is a $56 \mathrm{kDa}$ protein, and the gene has been cloned (Lee et al., 1982). Subsequent catabolism of galactose 6-phosphate involves three enzyme activities, galactose-6-phosphate isomerase, tagatose-6-phosphate kinase and tagatose-1,6-bisphosphate aldolase. The complete pathway of lactose utilization is shown in Fig. 1. This atypical route of lactose catabolism was first demonstrated in Staphylococcus aureus (Hengstenberg et al., 1969) and most of the characterization has been done in that species. The pathway has been found in Streptococcus faecalis (Heller \& Roschenthaler, 1978), Streptococcus mutans (Calmes, 1978), Streptococcus salivarius (Hamilton \& Lo, 1978), Streptococcus lactis (Bissett \& Anderson, 1974; McKay et al., 1969, 1970) and Lactobacillus casei (Premi et al., 1972). It assumed more than academic importance with its discovery in strains of lactic streptococci that are used as starter cultures for dairy fermentations. One of the most important roles of these starter bacteria in dairy fermentations is the catabolism of lactose with the eventual production of lactic acid as a major or sole end product. It has been established that the homofermentative metabolism of lactose in which only lactic acid is produced depends upon the use of the PTS and the subsequent catabolic steps that are described above. In consequence, characterization of the enzymes and the genes of this pathway in lactic streptococci is of considerable importance.

$\uparrow$ Present address: Kyodo Milk Industry Co. Ltd, 17-2 Koami-Cho Nihonbashi, Chuo-ku, Tokyo, Japan. 




Fig. I. The pathway for lactose catabolism in S. lactis.

The genes for the lactose-specific components of the PTS (factor III ${ }^{\text {lac }}$ and enzyme II $^{\text {lac}}$ ), phospho- $\beta$-D-galactosidase and the three enzymes of the tagatose phosphate pathway can be plasmid-encoded in lactic streptococci (Crow et al., 1983). In Streptococcus lactis strain NCDO 712, a $56.5 \mathrm{~kb}$ plasmid, pLP712, has been identified as encoding genes for lactose catabolism and proteinase production. The existence of both characters on one plasmid has aided the extensive deletion mapping of the plasmid, and a lactose genetic regi has been located on a detailed restriction endonuclease map of pLP712 (Gasson, 1983). Her describe the cloning of this region into Escherichia coli $\mathrm{K} 12$ and the expression and location of the lactic streptococcal gene for phospho- $\beta$-D-galactosidase.

\section{METHODS}

Bacterial strains and plasmids. All strains used in this study are listed in Table 1.

Media, reagents and enzymes. Media and conditions for growth of lactic streptococci have been described previously (Gasson, 1983). E. coli cultures were routinely grown on $L$ broth and $L$ agar. Buffer B consisted of $\left(1^{-1}\right)$ : $7 \mathrm{~g}$ disodium hydrogen phosphate, $3 \mathrm{~g}$ potassium dihydrogen phosphate, $4 \mathrm{~g}$ sodium chloride and $0 \cdot 1 \mathrm{~g}$ magnesium sulphate. Ampicillin, tetracycline, chloramphenicol and $\sigma$-nitrophenol- $\beta$-D-galactopyranoside-6-phosphate were 


\section{Table 1. S. lactis and E. coli strains}

Strain no.

S. lactis
NCDO 712
MG1363
MG1299
MG1393
MG1820
E. coli

HBI01

JA22 I

DS410
Properties

Wild-type $S$. lactis strain

NCDO 712 cured of prophage and plasmids MG1363 carrying plasmid pLP712

MG1363 carrying plasmid pMG393

MG1363 carrying plasmid pMG820

hsdS20 recAl3 supE44 lac $Y 1$ ara-14 galK2 xyl-5 proA 2 rpsL20 $\mathrm{mtl}-1$

hsdR recA lac $Y$ trpE leuB

$\min A \operatorname{rps} L$ tonA $\mathrm{Azi}^{\mathrm{R}} \mathrm{Thi}^{-}$
Reference or source*

Gasson (1983)

This paper

W. Brammer

*Address: W. Brammer, Department of Biochemistry, University of Leicester, UK.

purchased from Sigma. The antibiotics were used at final concentrations of $50 \mu \mathrm{g} \mathrm{ml}^{-1}, 20 \mu \mathrm{g} \mathrm{ml}^{-1}$ and $30 \mu \mathrm{g} \mathrm{ml}^{-1}$ respectively. Restriction endonuclease $C l a \mathrm{I}, B a m \mathrm{HI}$ and $X h o \mathrm{I}$ were obtained from BRL. Restriction endonucleases EcoRI, HindIII, PstI, SalI and T $\mathrm{T}_{4}$ DNA ligase and alkaline phosphatase were obtained from Boehringer Mannheim. ${ }^{35}$ S-Labelled L-methionine, 'Amplify' and reagents for prokaryotic DNA-directed translation were from Amersham.

Plasmid DNA preparation. Plasmid DNA from lactic streptococci was prepared as previously described (Gasson, 1983). Vector and recombinant plasmids were amplified in E. coli and the cells were lysed by the Brij 58sodium deoxycholate method of Humphreys et al. (1975). Covalently closed circular DNA was isolated by caesium chloride density gradient centrifugation in the presence of ethidium bromide (Radloff et al., 1967) and purified by extraction with isoamyl alcohol and dialysis against TE buffer (10 mm-Tris/HCl, $1 \mathrm{~mm}-\mathrm{EDTA}, \mathrm{pH} 8 \cdot 0)$. Agarose gel electrophoresis of plasmid DNA was as previously described (Gasson, 1983).

Digestion and ligation of DNA. Restriction endonuclease digestions were done using the enzyme manufacturer's recommended reaction buffer and complete digestion was confirmed by agarose gel electrophoresis of a sample. DNA preparations were treated with phenol/chloroform and chloroform/isoamyl alcohol and then precipitated with isopropanol at room temperature. Ligations were done with appropriate concentrations and ratios of DNA (Dugaiczyk \& Boyer, 1975) in $100 \mu$ l volumes of ligation buffer with 1-2 units of $\mathrm{T}_{4}$ DNA ligase at $10^{\circ} \mathrm{C}$ for $18 \mathrm{~h}$ or at $15^{\circ} \mathrm{C}$ for $8 \mathrm{~h}$.

Transformation of $E$. coli. Cells were grown to an $\mathrm{OD}_{450}$ of $0 \cdot 6$, chilled, centrifuged and resuspended in $0 \cdot 5$ vol. ice-cold $0 \cdot 1 \mathrm{M}$-magnesium chloride. After a second centrifugation, cells were resuspended in 0.5 vol. ice-cold $0.1 \mathrm{M}$ calcium chloride and held on ice for $30 \mathrm{~min}$. Cells were then centrifuged again and resuspended in 0.05 vol. icecold $0 \cdot 1 \mathrm{M}$-calcium chloride and held on ice overnight. Competent cells $(200 \mu \mathrm{l})$ and $100 \mu \mathrm{ISSC}(0 \cdot 15 \mathrm{M}$-sodium chloride, $15 \mathrm{~mm}$-sodium citrate, $\mathrm{pH} 7.0$ ) were added to DNA in a $1.5 \mathrm{ml}$ Eppendorf tube, gently mixed and held on ice for $30 \mathrm{~min}$ with occasional shaking. Tubes were transferred to a $42^{\circ} \mathrm{C}$ waterbath for $2 \mathrm{~min}$ and then returned to ice for $20 \mathrm{~min}$. Cells were added to $2 \mathrm{ml}$ broth and incubated at $37^{\circ} \mathrm{C}$ for $90 \mathrm{~min}$ before plating out on selective media.

Assay of phospho- $\beta$-D-galactosidase activity. Assays were done on toluene-treated whole cells or on cell-free extracts. $E$. coli cells grown to mid-exponential phase were washed twice and resuspended in $0.05 \mathrm{M}$-sodium phosphate buffer $\mathrm{pH} 7.0$. For toluene treatment, $1 \mathrm{ml}$ of cells concentrated to an $\mathrm{OD}_{\text {tion }}$ of 2.0 was shaken with a drop of acetone/toluene $(9: 1)$ for $10 \mathrm{~min}$ at $37^{\circ} \mathrm{C}$. E. coli cells were broken at $0^{\circ} \mathrm{C}$ by four $30 \mathrm{~s}$ bursts of ultrasonication with a microprobe. Lactic streptococci, grown to mid-exponential phase, were made into protoplasts by resuspending cells to an $\mathrm{OD}_{600}$ of 0.5 in $\mathrm{M} 17$ broth with $0.04 \mathrm{M}$-ammonium acetate, $0.001 \mathrm{M}$ magnesium acetate, $0.5 \mathrm{M}$-sucrose and $2 \mathrm{mg}$ lysozyme $\mathrm{ml}^{-1}$ and incubating at $37^{\circ} \mathrm{C}$ for $30 \mathrm{~min}$. After washing twice in protoplast buffer (Gasson, 1980), protoplasts were lysed by resuspension in $0.05 \mathrm{M}$-sodium phosphate buffer $\mathrm{pH} 7 \cdot 0$. Cell debris was removed by centrifugation at $25000 \mathrm{~g}$ for $30 \mathrm{~min}$. The toluene-treated cells and cell-free extracts were assayed for phospho- $\beta$-D-galactosidase activity by measuring $o$-nitrophenol released from $o$ nitrophenyl- $\beta$-D-galactopyranoside-6-phosphate as described by Okamoto \& Morichi (1979). Protein was measured using the Coomassie blue dye-binding assay (Bradford, 1976).

Minicells. These were prepared and used according to the method of Reeve $(1977,1979)$

Plasmid-carrying derivatives of $E$. coli DS410 were grown overnight in L broth containing an appropriate selective antibiotic. Differential centrifugation was used to partially purify the minicells, which were then subjected to two cycles of sucrose gradient centrifugation. The purified minicells were pelleted by centrifugation and resuspended in $\mathrm{M} 9$ minimal medium at an $\mathrm{OD}_{600}$ of 2.0. To label proteins, $100 \mu \mathrm{l}$ of minicells were placed in an Eppendorf tube with $2 \mu \mathrm{l}$ sodium ampicillin solution $\left(1.5 \mathrm{mg} \mathrm{ml}^{-1}\right)$ and incubated for $60 \mathrm{~min}$ at $37^{\circ} \mathrm{C}$. 
Approximately $25 \mu \mathrm{Ci}(\sim 930 \mathrm{kBq}){ }^{35} \mathrm{~S}$-labelled $\mathrm{L}$-methionine and $2 \mu \mathrm{l}$ Difco methionine assay medium were added and incubation was continued for a further $60 \mathrm{~min}$. To complete synthesis of partially labelled peptides, $10 \mu \mathrm{l}$ prewarmed methionine solution $\left(8 \mathrm{mg} \mathrm{m}^{-1}\right)$ was added and incubation was continued for $5 \mathrm{~min}$. The minicells were pelleted and resuspended in $60 \mu \mathrm{l}$ buffer B and $60 \mu 1$ SDS-sample buffer was added. Preparations were heated in a boiling water bath for $3 \mathrm{~min}$ and samples analysed by SDS-PAGE and fluorography.

DNA-directed translation. The bacterial cell-free coupled transcription-translation system of DeVries \& Zubay (1967) as modified by Zubay (1973) and Collins (1979) was used. Plasmid DNA was prepared without ribonuclease treatment and used either directly or after digestion with a restriction endonuclease. The reagents and protocol for DNA-directed protein synthesis were provided by Amersham.

SDS-PAGE. Proteins labelled with ${ }^{35}$ S were separated by SDS-PAGE according to the method of Laemmli \& Favre (1973). Fluorographs were prepared from gels by soaking in 'Amplify' and $1 \%(\mathrm{v} / \mathrm{v})$ glycerol, drying down and exposing to Kodak X-Omat S X-ray film at $-80^{\circ} \mathrm{C}$.

Transduction. Recipient bacteria $(100 \mu \mathrm{l})$, bacteriophage lysate $(100 \mu \mathrm{l})$ and $0 \cdot 1 \mathrm{M}$-calcium chloride $(50 \mu \mathrm{l})$ were mixed and left at room temperature for $15 \mathrm{~min}$, Dilutions were plated on lactose BCP indicator agar and incubated at $30^{\circ} \mathrm{C}$ for $48 \mathrm{~h}$.

\section{RESULTS}

\section{Deleted lactose plasmid}

S. lactis strain MG1299 was derived from the multiple-plasmid-carrying strain S. lactis 712 by the sequential elimination of cryptic plasmids to leave only the lactose and proteinase plasmid pLP712 (Gasson, 1983). Plasmid pLP712 is unstable and is readily fragmented by spontaneous deletion formation. Deletions sometimes remove one or both of the genetic regions for lactose utilization and proteinase production but sometimes cause no change in phenotype. Plasmid pLP712 and a large number of these deleted plasmids have been characterized by restriction endonuclease mapping. The genetic regions for lactose utilization, proteinase production, and replication have been located on a restriction map of pLP712 by correlating the deletion position with its effect on phenotype. Further characterization of these regions can be achieved by their cloning and introduction into organisms with better characterized genetic systems. In order to clone the lactose region into $E$. coli, a lactose mini-plasmid was constructed by combining two deletions of plasmid pLP712. The lactose plasmid was first transduced by the temperate phage $\phi \mathrm{T} 712$ into a plasmid-free $S$. lactis 712 derivative. Because the $\phi \mathrm{T} 712$ bacteriophage genome is smaller than plasmid pLP712 the phage head cannot accommodate the entire lactose plasmid during transduction. Consequently transduction selects a deleted lactose plasmid of a similar size to the bacteriophage genome. This 'transductional shortening' process was used to isolate one deletion of plasmid pLP712 (pMG393), and a second deletion was introduced by isolating a proteinase negative variant after repeatedly sub-culturing MG1393 in milk. The combined deletions reduced the $56.5 \mathrm{~kb}$ pLP712 plasmid to a $23.7 \mathrm{~kb}$ mini-plasmid, pMG820. The derivation of pMG820 and an independently constructed restriction map of the lactose mini-plasmid are shown in Fig. 2.

\section{Cloning pMG820 in E. coli $\mathrm{HB101}$}

Plasmid pMG820 was cut into two approximately equal pieces by restriction endonuclease $P$ st $\mathrm{I}$, and one $P$ stI site was within the lactose genetic region. The $P$ st $\mathrm{I}$ fragments were cloned into vector plasmid pAT153 (from C. Duggley, Porton Down, Salisbury, UK) and tetracyclineresistant transformants of $E$. coli $\mathrm{HB} 101$ were selected and screened for insertional inactivation of the vector's ampicillin-resistance gene. Clones were identified by their ampicillin-sensitive tetracycline-resistant phenotype, and by the size and restriction endonuclease patterns of their plasmids. Hybrid plasmids carrying each piece of pMG820 were readily obtained and an agarose gel illustrating this initial cloning experiment is shown in Fig. 3.

\section{In vitro construction of deleted derivatives}

$E$. coli clones carrying each of the two fragments of pMG820 were tested for the presence of phospho- $\beta$-D-galactosidase activity in toluene-treated cells and cell-free extracts. Enzyme activity was found only in clones with the smaller $10.4 \mathrm{~kb}$ segment of pMG820 (e.g. pSM5), showing the gene for phospho- $\beta$-D-galactosidase to be located on that segment of the plasmid. 

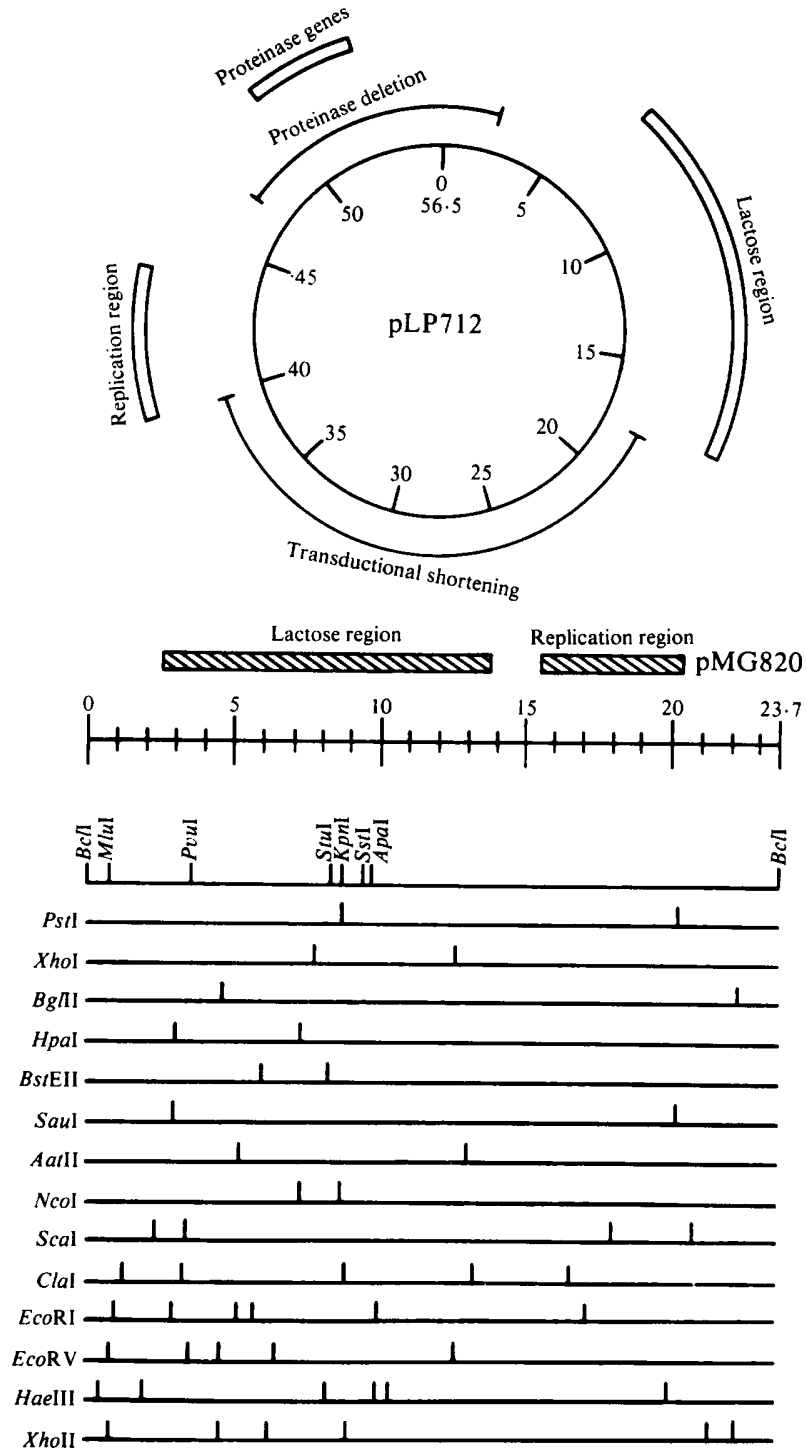

Fig. 2. Derivation of and restriction endonuclease map for double deletion plasmid pMG820. The location of the two deletions of pLP712 are shown together with an independently determined restriction map of the lactose mini-plasmid pMG820.

In order to localize further this phospho- $\beta$-D-galactosidase gene, plasmid pSM5 was transformed into the $E$. coli host JA221 and a series of deletions were introduced into the cloned $10.4 \mathrm{~kb}$ segment of pMG820 by using in vitro techniques (Fig. 4).

Digestion and re-ligation with restriction endonucleases EcoRI and HindIII were used to produce plasmids pSM 18 and pSM24 respectively. A HindIII fragment from pSM24 was then ligated into the tetracycline-resistance gene of pAT153 DNA that had been digested with HindIII and treated with alkaline phosphatase. Transformants resistant to ampicillin were selected and clones carrying the HindIII streptococcal DNA fragment in each possible orientation were isolated. This produced plasmids pSM52 and pSM54. Plasmid pSM52 was digested with ClaI, re-ligated and transformed into $E$. coli JA221, selecting for ampicillin resistance; plasmids such as pSM110 were isolated. A fragment from pSM 24 bounded by the 


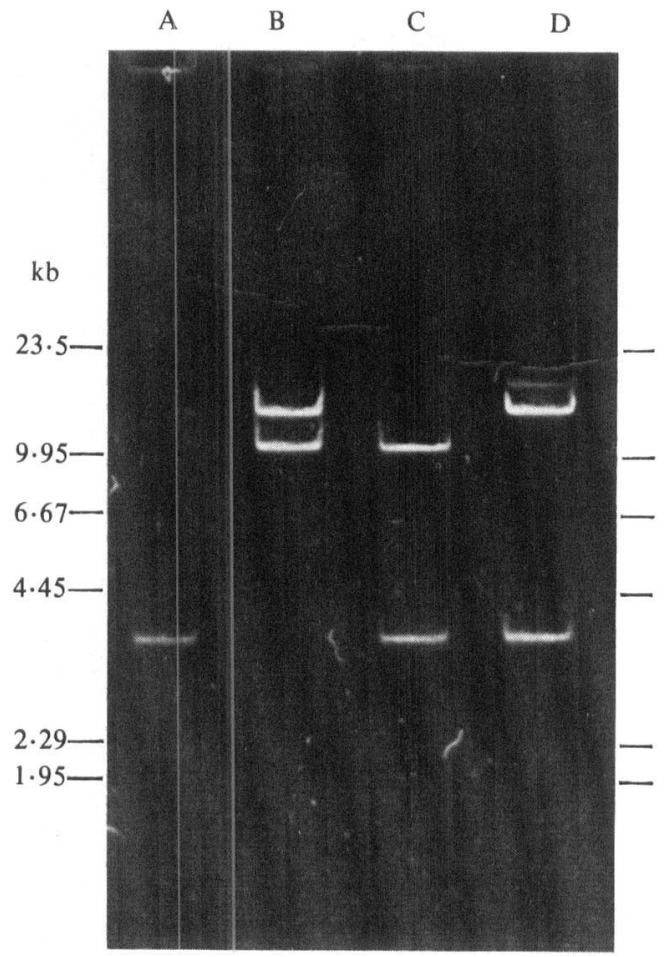

Fig. 3. Plasmid pMG820 cloned into E. coli vector pAT 153. Purified plasmid DNA was digested with restriction endonuclease $P_{s t} \mathrm{I}$ and separated by agarose gel electrophoresis. The tracks show pAT 153 (A), pMG820 (B) and the two possible clones, pSM5 (C), which is pAT153 with a $10.4 \mathrm{~kb}$ pMG820 insert, and pSM4 (D), which is pATI53 with a $13.3 \mathrm{~kb}$ pMG820 insert.

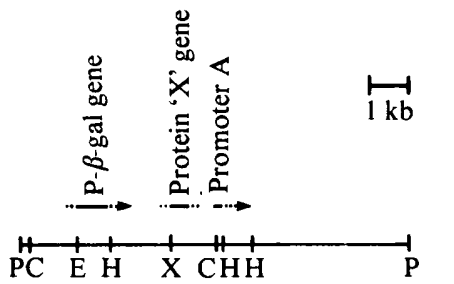

$\begin{array}{cccc}\text { P- } \beta \text {-gal } & \begin{array}{c}\text { P- } \beta \text {-gal } \\ \text { activity }\end{array} & \begin{array}{c}\text { Protein } \\ \text { ' } \mathrm{X} \text { ' }\end{array} & \begin{array}{c}\text { Promoter } \\ \text { A activity }\end{array} \\ & (\mathrm{kDa}) & (\mathrm{kDa}) & \end{array}$

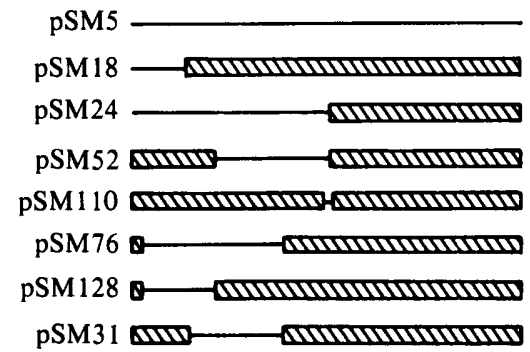

$\begin{array}{cccc}+ & \text { NT } & \text { NT } & \text { NT } \\ - & - & - & \text { NT } \\ + & 58 & 37 & + \\ - & - & 37 & + \\ - & - & - & + \\ + & 58 & - & \text { NT } \\ - & 16 & - & \text { NT } \\ - & - & - & \text { NT }\end{array}$

Fig. 4. Deletion map of stretpcoccal DNA cloned in pSM5. Hatched areas indicate regions deleted. The presence of phospho- $\beta$-D-galactosidase (P- $\beta$-gal) activity is indicated. Radiolabelled proteins synthesized in vivo by minicells and in vitro by coupled transcription and translation are shown by quoting the protein sizes in $\mathrm{kDa}$. Promoter A activity is the presence of a tetracycline-resistant phenotype in clones with streptococcal DNA adjacent to the HindIII site of pAT153; a detailed description of this promoter will be published separately. P, PstI; C, ClaI : E, Eco RI ; H, HindIII; X. XhoI. NT, Not tested. 
Table 2. Phospho- $\beta$-D-galactosidase activities

Specific activities were measured after growth in the presence of glucose or lactose and are expressed as $\mu \mathrm{mol} \sigma$-nitrophenol released (mg protein) ${ }^{-1} \mathrm{~min}^{-1}$. Two representative results are shown. E. coli has no detectable activity.

\begin{tabular}{|c|c|c|}
\hline \multirow[t]{2}{*}{ Strain } & \multicolumn{2}{|c|}{$\begin{array}{l}\text { Phospho- } \beta \text {-D-galactosidase } \\
\text { specific activity after growth on }\end{array}$} \\
\hline & Glucose & Lactose \\
\hline \multirow[t]{2}{*}{ S. lactis MG1299 } & $0 \cdot 28$ & $2 \cdot 44$ \\
\hline & $0 \cdot 20$ & $1 \cdot 48$ \\
\hline \multirow[t]{2}{*}{ S. lactis MG1820 } & $0 \cdot 15$ & 1.39 \\
\hline & $0 \cdot 19$ & 1.72 \\
\hline \multirow[t]{2}{*}{ E. coli $\mathrm{HB} 10 \mathrm{l}(\mathrm{pSM} 5)^{*}$} & 0.04 & 0.06 \\
\hline & 0.03 & 0.04 \\
\hline \multirow[t]{2}{*}{ E. coli JA221(pSM24)* } & $0 \cdot 27$ & $0 \cdot 23$ \\
\hline & 0.68 & 0.59 \\
\hline \multirow[t]{2}{*}{ E. coli JA221(pSM76)* } & 0.03 & 0.05 \\
\hline & 0.03 & 0.04 \\
\hline
\end{tabular}

*Plasmid carries the streptococcal phospho- $\beta$-D-galactosidase gene.

ClaI and XhoI sites was excised and directionally cloned into pAT153 DNA that had been digested with ClaI and SalI. Plasmid pSMi76 is representative of the plasmids isolated from the ampicillin-resistant, tetracycline-sensitive clones. In similar directional cloning experiments, DNA fragments bounded by ClaI-HindIII sites or EcoRI-XhoI sites were excised and cloned into pAT153 DNA digested respectively with ClaI-HindIII or EcoRI-SalI. This produced plasmids pSM128 and pSM31 respectively.

\section{Phospho- $\beta$-D-galactosidase activity}

The presence of phospho- $\beta$-D-galactosidase activity in these in vitro-constructed derivatives of plasmid pSM5 was tested using both toluene-treated cells and cell-free extracts. Enzyme activity was detected only for plasmids pSM24 and pSM76, and this defined a region between the lefthand ClaI site and the XhoI site as encoding the gene for phospho- $\beta$-D-galactosidase (Fig. 4).

Specific activities were calculated for $E$. coli cell-free extracts of the positive strains. In addition the specific activity of phospho- $\beta$-D-galactosidase in the parent $S$. lactis strains MG1299 and MG1820 was calculated using osmotically lysed, concentrated protoplast preparations. This alternative procedure was adopted because lactic streptococci are not readily broken by ultrasonication. Cells were grown both in the presence of lactose and glucose to test for inducibility or repression (Table 2).

\section{Detection of ${ }^{35}$ S-labelled proteins}

The proteins encoded by the cloned streptococcal DNA fragments were further characterized by using $E$. coli minicells and the Zubay in vitro system for coupled transcription and translation of DNA. The $S$. lactis-encoded proteins detected by these methods are summarized in Fig. 4. Phospho- $\beta$-D-galactosidase has been purified from $S$. lactis MG1820 and found to have a molecular mass of $60 \mathrm{kDa}$ (S. Maeda, unpublished data). The presence of a $58 \mathrm{kDa}$ protein, resolved both by minicell and by Zubay labelling techniques, was correlated with the presence of phospho- $\beta$-D-galactosidase activity (Figs 5 and 6). This correlation was confirmed by showing that in the Zubay labelling system digestion of pSM76 DNA with HindIII eliminated the $58 \mathrm{kDa}$ protein, whereas digestion with PstI did not (Fig. 5). An intensely labelled protein band of $42 \mathrm{kDa}$ was also produced by pSM76 and by some of the other plasmids. The presence of this band could not be correlated with any particular area of the cloned streptococcal DNA. Furthermore, in the Zubay labelling system it was eliminated by PstI digestion but not by HindIII digestion (Fig. 5). It is possible that this protein is an artefactual polypeptide associated with the insertionally inactivated ampicillin-resistance gene of the pAT153 vector. 


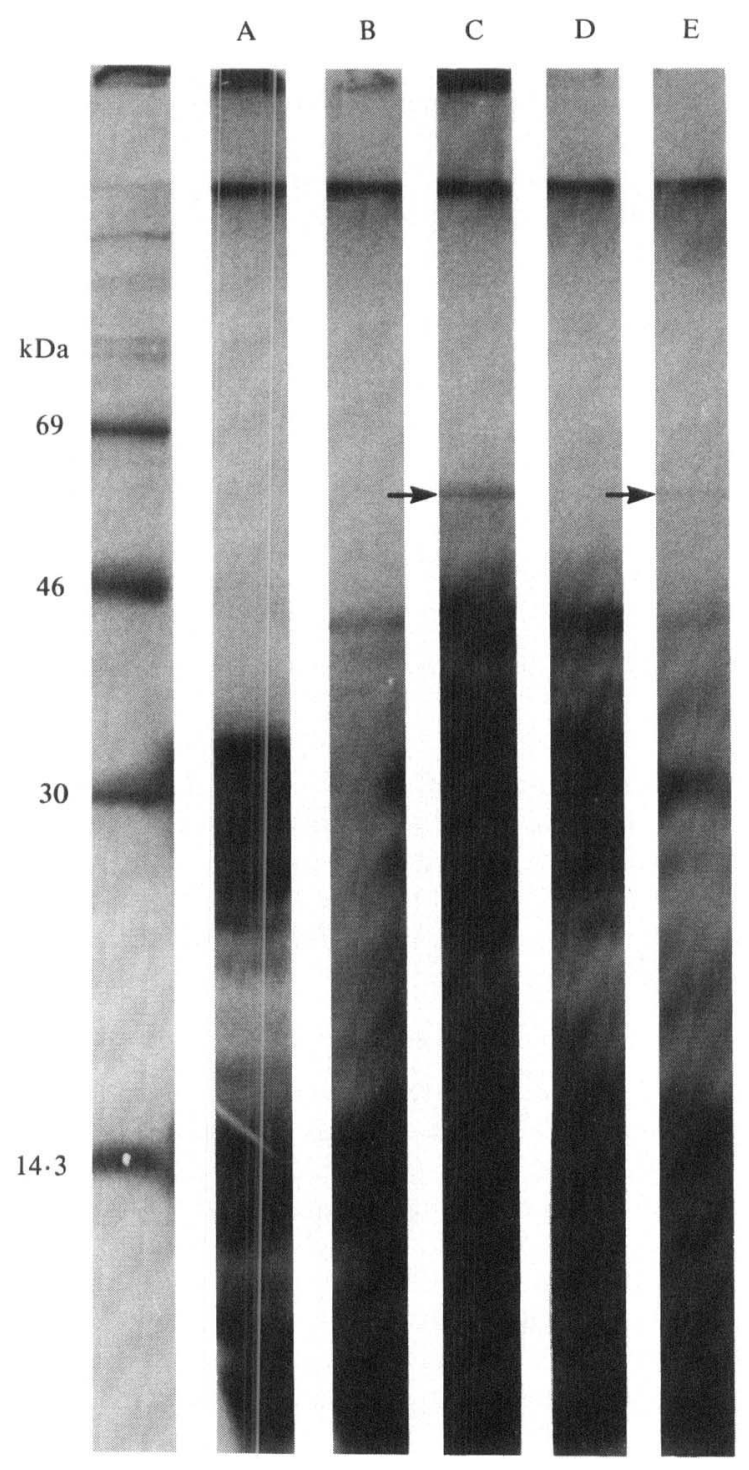

Fig. 5. In vitro coupled transcription and translation of pSM76 DNA. The fluorograph shows ${ }^{35} \mathrm{~S}-$ labelled proteins produced by in vitro coupled transcription and translation of pAT153 DNA (A), pAT153 DNA pre-digested with PstI (B), pSM76 DNA (C), pSM76 DNA pre-digested with HindIII (D) or Pst (E). The phospho- $\beta$-D-galactosidase protein is arrowed. A protein of $42 \mathrm{kDa}$ is also produced by pSM76 DNA but it is eliminated by $P$ st I digestion $(\mathrm{E})$ and is probably an artefact associated with the ampicillin-resistance gene of pAT153.

Plasmid pSM128 lacks both phospho- $\beta$-D-galactosidase activity and the associated $58 \mathrm{kDa}$ protein. However, a novel polypeptide of $16 \mathrm{kDa}$ was clearly detected in minicells carrying pSM128 (Fig. 6). Because pSM128 carries the region known to be essential for phospho- $\beta$-Dgalactosidase enzyme activity, it is possible that the $16 \mathrm{kDa}$ protein represents a truncated polypeptide formed by expression of the incomplete gene for phospho- $\beta$-D-galactosidase. This could result from the fusion of the $5^{\prime}$ end of the coding sequence to a new translation stop codon.

In both the minicell and the Zubay labelling systems plasmids pSM24 and pSM52 produced an additional protein of $37 \mathrm{kDa}$. This protein was not produced by the other plasmid clones that 




Fig. 6. Proteins synthesized in $E$. coli minicells. The fluorograph shows ${ }^{35}$ S-labelled proteins produced by $E$. coli minicells carrying pAT153 (A), pSM31 (B), pSM52 (C), pSM128 (D) and pSM76 (E). The arrows indicate the $37 \mathrm{kDa}$ protein ' $\mathrm{X}$ ' $(\mathrm{C})$, the $16 \mathrm{kDa}$ truncated phospho- $\beta$-D-galactosidase protein (D) and the $58 \mathrm{kDa}$ intact phospho- $\beta$-D-galactosidase protein $(\mathrm{E})$.

were tested (Figs 5 and 6). This suggests that an additional gene of unknown function is located between the left-hand HindIII sites (Fig. 4). The $37 \mathrm{kDa}$ polypeptide produced by expression of this gene has been designated 'protein $\mathrm{X}$ '.

\section{DISCUSSION}

Activity of the key $S$. lactis lactose splitting enzyme, phospho- $\beta$-D-galactosidase, was found to depend upon the presence of a region of plasmid pLP712 located between co-ordinates 13.8 and 1.1 on the pLP712 restriction map (Fig. 2). Enzyme activity was correlated with the presence of a $58 \mathrm{kDa}$ radiolabelled protein that was identified after gene expression of DNA cloned in $E$. coli. This size of protein is in good agreement with the $56 \mathrm{kDa}$ phospho- $\beta$-D-galactosidase from $L$. casei that has been purified, and also cloned into E. coli (Lee et al., 1982). A novel $16 \mathrm{kDa}$ protein was produced by deletion derivative pSM128. This could be a truncated phospho- $\beta$-Dgalactosidase and suggests a likely clockwise direction (Fig. 2) for transcription of phospho- $\beta$-Dgalactosidase gene. A second gene from within the lactose genetic region was identified by detecting a $37 \mathrm{kDa}$ protein radiolabelled after expression of pLP712 DNA cloned in $E$. coli. The gene for this protein, which has been designated 'protein X', was located between co-ordinates 15.5 and 18.2 on the pLP712 restriction map (Fig. 2).

As has been found for other lactic streptococci (McKay et al., 1970), the phospho- $\beta$-Dgalactosidase enzyme activity of $S$. lactis 712 was induced by growth in the presence of lactose or galactose. When the gene was cloned into $E$. coli only about $4 \%$ of the fully induced level of activity was found and inducibility could not be demonstrated. One possible reason for lack of induction was the $\mathrm{LacY}^{-}$phenotype of the E. coli host strains $\mathrm{HB} 101$ and JA221. However, this was eliminated by also checking the clones in lactose-positive hosts; identical results were found 
(data not shown). The lack of inducibility in $E$. coli is probably either because the correct inducer molecule is not produced in that host or because a control component(s) has been deleted during cloning of the phospho- $\beta$-D-galactosidase. The specific activity of phospho- $\beta$-D-galactosidase was markedly higher in clone pSM24 but this observation is unexplained.

\section{REFERENCES}

BissetT, D. L. \& ANDERSON, R. L. (1974). Lactose and D-galactose metabolism in group $\mathrm{N}$ streptococci: presence of enzymes for both the D-galactose-1phosphate and D-tagatose-6-phosphate pathways. Journal of Bacteriology 117, 318-320.

BRADFORD, M. M. (1976). A rapid and sensitive method for the quantitation of microgram quantities of protein, utilizing the principle of protein-dye binding. Analytical Biochemistry 12, 248-254.

CaLmes, R. (1978). Involvement of phosphoenolpyruvate in the catabolism of caries-conducive disaccharides by Streptococcus mutans: lactose transport. Infection and Immunity 19, 934-942.

Collins, J. (1979). Cell-free synthesis of proteins coding for mobilization functions of ColEl and transposition functions of Tn3. Gene 6, 29-42.

Crow, V. L., Davey, G. P., Pearce, L. E. \& Thomas, T. D. (1983). Plasmid linkage of the D-tagatose-6phosphate pathway in Streptococcus lactis: effect on lactose and galactose metabolism. Journal of Bacteriology 153, 76-83.

DeVRIES, J. K. \& Zubay, G. (1967). DNA-directed peptide synthesis. II. The synthesis of the $\alpha$ fragment of the enzyme $\beta$-galactosidase. Proceedings of the National Academy of Sciences of the United States of America 57, 1010-1012.

Dugaiczyk, A. \& Boyer, H. W. (1975). Ligation of EcoRI endonuclease-generated DNA fragments into linear and circular structures. Journal of Molecular Biology 96, 171-184.

Gasson, M. J. (1980). Production, regeneration and fusion of protoplasts in lactic streptococci. FEMS Microbiology Letters 9, 99-102.

Gasson, M. J. (1983). Plasmid complements of Streptococcus lactis NCDO 712 and other lactic streptococci after protoplast-induced curing. Journal of Bacteriology 154, 1-9.

Hamilton, I. R. \& Lo, G. Y. C. (1978). Co-induction of $\beta$-galactosidase and the lactose-P-enolpyruvate phosphotransferase system in Streptococcus salivarius and Streptococcus mutans. Journal of Bacteriolog. 136, $900-908$

Heller, K. \& Roschenthaler, R. (1978). $\beta$-Dphosphogalactosidase galactohydrolase of Streptococcus faecalis and the inhibition of its synthesis by glucose. Canadian Journal of Microbiology 24, 512519.
Hengstenberg, W., Penberthy, W. K., Hill, K. L. \& MORSE, M. L. (1969). Phosphotransferase system of Staphylococcus aureus: its requirement for the accumulation and metabolism of galactosides. Journal of Bacteriology 99, 383-388.

Humphreys, G. O., Willshaw, G. A. \& ANDERSON, E. S. (1975). A simple method for the preparation of large quantities of pure plasmid DNA. Biochimica et biophysica acta 383, 457-463.

LAEMmLI, U. K. \& FAVRE, M. (1973). Maturation of the head of bacteriophage $T_{4}$. I. DNA packaging events. Journal of Molecular Biology 80, 575-599.

LeE, L. L., Hansen, J. B., Jagusztyn-Krynicka, E. K. \& Chassy, B. M. (1982). Cloning and expression of the $\beta$-D-phosphogalactoside galactohydrolase gene of Lactobacillus casei in Escherichia coli $\mathrm{K} 12$. Journal of Bacteriology 152, 1138-1146.

MCKay, L. L., Walter, L. A., SANdine, W. E. \& ElLIKER, P. R. (1969). Involvement of phosphoenolpyruvate in lactose utilization by group $\mathrm{N}$ streptococci. Journal of Bacteriology 99, 603-610.

McKay, L. L., Miller, A., Sandine, W. E. \& Elliker, P. R. (1970). Mechanisms of lactose utilization by lactic acid streptococci: enzymatic and genetic analyses. Journal of Bacteriology 102, 804809.

OKAмOTo, T. \& MORICHI, T. (1979). Distribution of $\beta$ galactosidase and $\beta$-phosphogalactosidase activity among lactic streptococci. Agricultural and Biological Chemistry 43, 2389-2390.

Premi, L., Sandine, W. E. \& Elliker, P. R. (1972). Lactose-hydrolysing enzymes of Lactobacillus species. Applied Microbiology 24, 51-57.

Radloff, R., Bauer, W. \& Vinograd, J. (1967). A dye-buoyant-density method for the detection and isolation of closed circular duplex DNA: the closed circular DNA in HeLa cells. Proceedings of the National Academy of Sciences of the United States of America 57, 1514-1521.

REEVE, J. N. (1977). Bacteriophage infection of minicells. Molecular and General Genetics 158, 73-79.

ReEve, J. N. (1979). Use of minicells for bacteriophage-directed polypeptide synthesis. Methods in Enzymology 68, 493-503.

ZUBAY, G. (1973). In vitro synthesis of protein in microbial systems. Annual Reriew of Genetics 7, 267287. 